\title{
Research on the Coordinated Evaluation System of Economic Development and Social Governance in Beijing-Tianjin-Hebei Region
}

\author{
Dan $\mathrm{Wu}^{1, *}$ Xiaoqian Xiang ${ }^{1}$ \\ ${ }^{I}$ School of Economics and Management, North China University of Technology, Beijing 100144, China \\ *Corresponding author. Email: wu_daniel@163.com
}

\begin{abstract}
Through a comprehensive comparison and evaluation of the differences in economic development and social governance of Beijing-Tianjin-Hebei region in different periods, this article analyzes the main factors affecting the economic development and social governance of Beijing-Tianjin-Hebei region, which plays an important support role in accelerating the coordination process of economic development and social governance in BeijingTianjin-Hebei region. It uses the weighting method, the relative development degree method and the coupling coordination degree model to evaluate the dynamic changes of Beijing-Tianjin-Hebei region's economic development level and social governance level in different periods, evaluate the level of coordinated economic development and the level of coordinated social governance of Beijing-Tianjin-Hebei region, calculate the relative development level of economic development and social governance in Beijing-Tianjin-Hebei region, and dynamically evaluate the coordination level of economic development and social governance in Beijing-TianjinHebei region.
\end{abstract}

Keywords: Beijing-Tianjin-Hebei region, Economic development, Social governance, Coordinated evaluation, Level.

\section{INTRODUCTION}

The report of the 19th National Congress of the Communist Party of China put forward "implementing the new development concept and building a modern economic system", emphasizing that efforts must be made to accelerate the construction of an industrial system for the coordinated development of science and technology, the real economy, modern finance, and human resources. Improving economic development ability is an inexhaustible driving force for social governance in Beijing-TianjinHebei region, and promoting the coordinated development of economic development and social

*Funds: General Project of Beijing Natural Science Foundation "Research on the Two-way Optimal Adaptation of Water Resources and Industrial Structure Under the Coordinated Development of Beijing-Tianjin-Hebei Region" (No. 9202005); Yuyou Talent Project of North China University of Technology "Research on the Evaluation System of Beijing-Tianjin-Hebei Region's Resource Energy Consumption Management Performance and Its Cooperative Governance Capability from the Perspective of Technological Innovation" (No. XN020035). governance is one of the focuses of the work in Beijing-Tianjin-Hebei region.

Beijing's core leading role and major issues such as the governance of major city diseases, the upgrading of Tianjin's and Hebei's industrial structure, and the acceptance of non-capital functions have led to challenges for the economic coordinated development of Beijing-Tianjin-Hebei region [1-3]: the large development gap among Beijing, Tianjin and Hebei has promoted the oneway flow of factors; with the "air suction phenomenon", the integration efficiency is reduced [4-7]; there is no benign interaction within the industry, the functional complementation is not strong, the competition is greater than cooperation, and phenomena such as repeated investment and construction are serious [8-9]. The design of evaluation indicators for economic development in Beijing-Tianjin-Hebei region mainly includes indicators such as economic scale, level, benefit, structure, quality, and environment [1-9]. The social collaborative governance of Beijing-Tianjin- 
Hebei region has problems such as the uncoordinated tension between the center and the periphery, the concentration of resources in the center and the lack of resources in the periphery, significant differences in the quality of public services, and a high degree of non-equalization, and the main reason is the gap between the BeijingHebei region and the Tianjin-Hebei region, and the degree of non-equalization is still widening [10-14]. In general, Beijing and Tianjin have relatively low levels of social system vulnerability, while Hebei Province has a relatively high level of social system vulnerability [15-16]. The design of social governance evaluation indicators in the BeijingTianjin-Hebei region mainly includes indicators such as public services, people's lives, medical education, living environment, social structure, and social welfare and so on[10-20].

Based on the findings of the existing research literature, the existing evaluation methods emphasize the static evaluation of the BeijingTianjin-Hebei region's economic development level and social governance level in a specific year, lacking in dynamic comparative analysis of the level of economic development and social governance of Beijing-Tianjin-Hebei region in different periods as well as a comprehensive evaluation of the coordination level between the economic development and social governance of Beijing-Tianjin-Hebei region. To this end, this article adopts weighting method, relative development degree method and coupling coordination degree model to dynamically measure, compare and analyze the economic development

$$
\begin{aligned}
& \qquad E_{j}(t)=\frac{W_{j 1}(t)}{W_{j 2}(t)} \\
& \left\{\begin{array}{l}
W_{j k}(t)=\sum_{i=1}^{m}\left[w_{k i} \cdot x_{j k i}(t)\right] \\
x_{j k i}(t)=\left\{\begin{array}{l}
a_{j k i}(t)-\min a_{j k i}(t) \\
\max a_{j k i}(t)-\min a_{j k i}(t) \\
\max a_{j k i}(t)-a_{j k i}(t)
\end{array}\right.
\end{array}\right. \\
& \text { development level of the economic development } a_{j k i}(t)-\min a_{j k i}(t) \\
& \text { and social governance of the region in the } t \\
& \text { period. } W_{j k}(t) \text { is the development level of the } k \\
& \text { dimension of the } j \text { region in the } t \text { period ( } k=1 \\
& \text { and } k=2 \text { represent the two dimensions of }
\end{aligned}
$$

level and social governance level of BeijingTianjin-Hebei region in different periods, calculate the relative development level of economic development and social governance in BeijingTianjin-Hebei region, and comprehensively evaluate the level of coordinated economic development and the level of coordinated social governance in the Beijing-Tianjin-Hebei region. And it will also dynamically evaluates the coordination level of economic development and social governance in the Beijing-Tianjin-Hebei region, in order to explore key constraints of the level of coordinated development economy and the level of coordinated social governance, so as to guide the coordinated economic development and coordinated social governance of Beijing-TianjinHebei region.

\section{EVALUATION METHOD OF THE COORDINATION BETWEEN ECONOMIC DEVELOPMENT AND SOCIAL GOVERNANCE IN BEIJING-TIANJIN-HEBEI REGION}

It adopts the weighted aggregate index method to construct the development level evaluation model of economic development and social governance in the Beijing-Tianjin-Hebei region. It uses the relative development degree model to measure the relative development level of economic development and social governance in the Beijing-Tianjin-Hebei region. The above can be described in the following formula:

\section{$a_{j k i}$ is the efficient indicator \\ $a_{j k i}$ is the cost indicator}

economic development and social governance respectively), $x_{j k i}(t)$ is the dimensionless index value, $a_{j k i}(t)$ is the $i$ index value of the $k$ dimension of the $j$ region in the $t$ period, and $\max a_{j k i}(t)$ and $\min a_{j k i}(t)$ are respectively the optimal value and the worst value of the ${ }^{i}$ index 
value of the $k$ dimension in the ${ }^{j}$ region during the $t$ period. $w_{k i}$ is the weight of the $i$ index of the $k$ dimension, and the variation coefficient method can be used to determine the index weight of economic development and social governance.

It constructs a coupled coordinated development model to evaluate the level of coordinated economic development and the level of coordinated social governance in the Beijing-Tianjin-Hebei region, which can be expressed as the following formula:

$$
\begin{aligned}
& D_{k}(t)=\sqrt{C_{k}(t) \cdot P_{k}(t)} \\
& \left\{\begin{array}{l}
C_{k}(t)=\left[\frac{\prod_{j=1}^{2} W_{j k}(t)}{P_{k}(t)}\right]^{\frac{1}{j}} \\
P_{k}(t)=\frac{1}{j} \sum_{j=1}^{2} W_{j k}(t)
\end{array}\right.
\end{aligned}
$$

In formula (2), $D_{k}(t)$ is the collaborative level of the $k$ dimension in the $t$ period, and $C_{k}(t)$ is the coupling correlation degree of the $k$ dimension in the $t$ period. $P_{k}(t)$ is the coordination degree of the $k$ dimension in the $t$ period.

In a similar way, it constructs a coupled coordinated development model to dynamically evaluate the level of coupling and coordination of economic development and social governance in

Table 1. Coordination rating and stage of economic development and social governance in the Beijing-Tianjin-

Hebei region

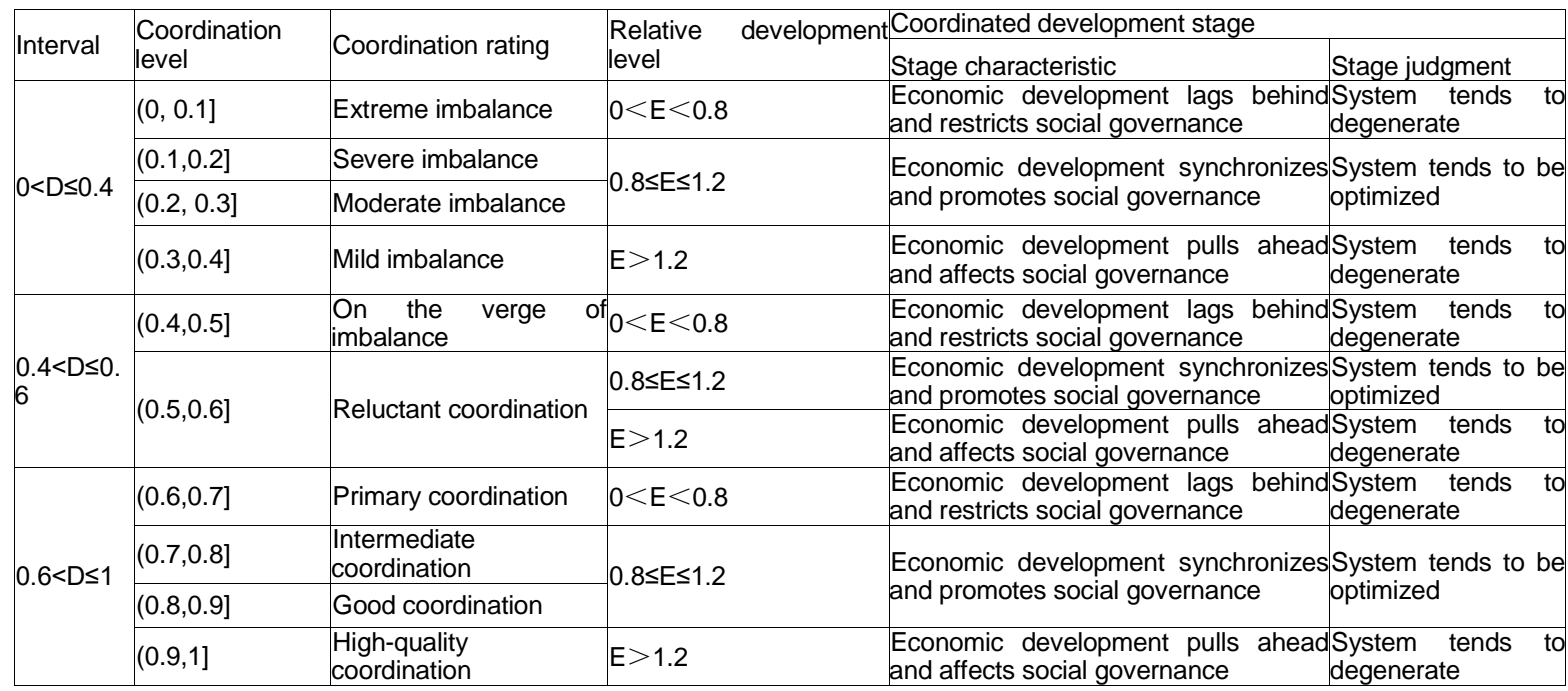

Beijing-Tianjin-Hebei region, which can be expressed as the following formula:

$$
\begin{gathered}
D_{j}(t)=\sqrt{C_{j}(t) \cdot P_{j}(t)} \\
\left\{\begin{array}{l}
C_{j}(t)=\left[\frac{\prod_{k=1}^{2} W_{j k}(t)}{P_{j}(t)^{k}}\right]^{\frac{1}{k}} \\
P_{j}(t)=\frac{1}{k} \sum_{k=1}^{2} W_{j k}(t)
\end{array}\right.
\end{gathered}
$$

In formula (3), $D_{j}(t)(j=1,2,3,4)$ is the coordination level of economic development and social governance in the $j$ region during the $t$ period, where $j=1, j=2, j=3$, and $j=4$ are Beijing, Tianjin, Hebei, and Beijing-Tianjin-Hebei as a whole respectively. $C_{j}(t)$ is the degree of coupling and correlation between economic development and social governance in the ${ }^{j}$ region during the $t$ period. $P_{j}(t)$ is the coordination degree between the economic development and social governance of the $j$ region during the $t$ period.

According to formula (1) to formula (3), this article refers to the existing literature grading results and judges the coordination rating and stage of scientific and technological innovation and ecological construction in the Beijing-TianjinHebei region, as shown in "Table 1". 


\section{DYNAMIC EVALUATION OF THE DEVELOPMENT LEVEL OF ECONOMIC DEVELOPMENT AND SOCIAL GOVERNANCE IN BEIJING-TIANJIN-HEBEI REGION}

It refers to policy documents such as the "Beijing-Tianjin-Hebei Coordinated Development Plan" and "Beijing-Tianjin-Hebei National Economic and Social Development Plan During the 13th Five-Year Plan Period" to clarify the "policyoriented" indicators of economic development and social governance in the Beijing-Tianjin-Hebei region. At the same time, it also refers to the core journal literature with the theme of "BeijingTianjin-Hebei, economic development, and social governance", and adopts the literature combing method to determine the "document-referred" indicators for the economic development and social governance of the Beijing-Tianjin-Hebei region. Combining the two categories of "policy-oriented" indicators and "document-referred" indicators, the evaluation indicators for the coordination of economic development and social governance in the Beijing-Tianjin-Hebei region can be obtained (see "Table 2").

Table 2. Evaluation indicators of the coordination between economic development and social governance in

Beijing-Tianjin-Hebei region

\begin{tabular}{|c|c|c|c|}
\hline \multirow{2}{*}{ Dimension } & \multicolumn{2}{|l|}{ Indicator } & \multirow{2}{*}{ Unit } \\
\hline & First-grade indicator & Second-grade indicator & \\
\hline \multirow{5}{*}{$\begin{array}{l}\text { Economic } \\
\text { development }\end{array}$} & \multirow{3}{*}{ Economic scale } & GDP growth & $\%$ \\
\hline & & Total retail sales of social consumer goods & 100 million yuan \\
\hline & & Industrial added value & 100 million yuan \\
\hline & Economic structure & Ratio of output value of the tertiary industry in GDP & $\%$ \\
\hline & Economic quality & Overall labor productivity & Yuan / person \\
\hline \multirow{6}{*}{$\begin{array}{l}\text { Social } \\
\text { governance }\end{array}$} & $\begin{array}{l}\text { Improvement } \\
\text { livelihood }\end{array}$ & $\begin{array}{l}\text { Urban registered unemployment rate } \\
\text { Year-end balance of RMB savings deposits of urban and } \\
\text { rural residents }\end{array}$ & $\begin{array}{l}\% \\
100 \text { million yuan }\end{array}$ \\
\hline & Educational governance & $\begin{array}{l}\text { Number of students enrolled in general institutes of higher } \\
\text { education } \\
\begin{array}{l}\text { Student-teacher ratio in general institutes of higher } \\
\text { education }\end{array} \\
\text { Local fiscal expenditure on education }\end{array}$ & \begin{tabular}{|l|} 
Ten thousand people \\
100 million yuan
\end{tabular} \\
\hline & $\begin{array}{l}\text { Post and telecommunications } \\
\text { scale }\end{array}$ & $\begin{array}{l}\text { Local tiscal expenditure on education } \\
\text { Year-end mobile phone users }\end{array}$ & \begin{tabular}{|l|}
100 million yuan \\
$\begin{array}{l}\text { Ten thousand } \\
\text { households }\end{array}$
\end{tabular} \\
\hline & Traffic scale & Length of railroad lines in service & $\begin{array}{l}\text { Ten thousand } \\
\text { kilometers }\end{array}$ \\
\hline & Medical improvement & Number of beds in medical and health institutions & Ten thousand beds \\
\hline & Insurance scale & $\begin{array}{l}\text { Year-end number of insured people in the basic medical } \\
\text { insurance for urban employees }\end{array}$ & Ten thousand people \\
\hline
\end{tabular}

\subsection{Dynamic Comparison of Economic Development Level}

Taking 2009 as the base year, it determines the economic development level of the Beijing-TianjinHebei region from 2010 to 2018 , as shown in "Figure 1". 


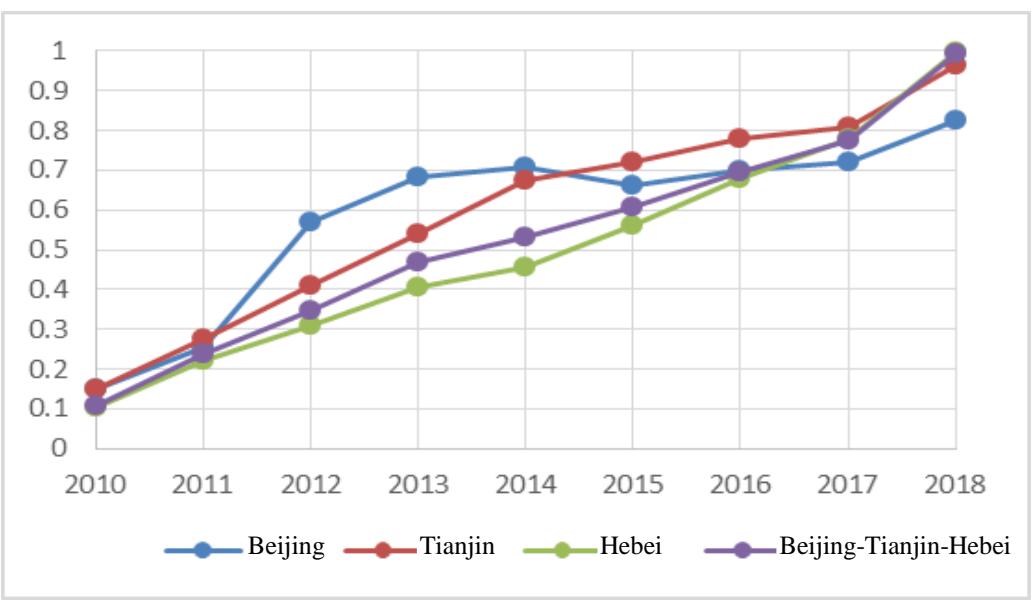

Figure 1 The level of economic development in the Beijing-Tianjin-Hebei region.

It can be seen from "Figure 1" that from 2010 to 2018, the overall economic development level of the Beijing-Tianjin-Hebei region showed an increasing trend; the changes in the economic development level of the Beijing-Tianjin-Hebei region showed a multi-temporal nature. Among them:

First, from 2010 to 2016, the overall economic development level of the Beijing-Tianjin-Hebei region showed a change rule of Tianjin (0.795)> Beijing (0.746)> Hebei (0.711). This was due to the strong economic development momentum of Tianjin, which gradually highlighted its advantages in terms of economic development scale, structure and quality. At this time, the total retail sales of consumer goods in Tianjin increased from 286.02 billion yuan in 2010 to 563.58 billion yuan in 2016 , with an average annual increase of 46.26 billion yuan and an average annual growth rate of $16 \%$; the industrial added value increased from 441.085 billion yuan in 2010 to 680.513 billion yuan in 2016, with an average annual growth of 39.9 billion yuan and an average annual growth rate of $9 \%$; the ratio of output value of the tertiary industry in GDP increased from $45.7 \%$ in 2010 to $56.6 \%$ in 2016; the overall labor productivity increased from 132,929 yuan/person in 2010 to 198,285 yuan/person in 2016, with an average annual growth of 10,893 yuan/person and an average annual growth rate of $9 \%$.

Second, in 2017, the economic development level of the Beijing-Tianjin-Hebei region showed the rule of Hebei (0.791)> Tianjin (0.790)> Beijing (0.766). This was because that Hebei was driven by the economic integration of Beijing-Tianjin-Hebei region, and its economic development was rapid. At this time, the total retail sales of consumer goods in
Hebei increased by $11 \%$ year-on-year; the industrial added value increased by $3 \%$ year-onyear; the ratio of output value of the tertiary industry in GDP increased by 5\% year-on-year; the overall labor productivity increased by $8 \%$ year-onyear.

Third, in 2018, the economic development level of the Beijing-Tianjin-Hebei region showed the rule of Beijing (0.804)> Tianjin (0.768)> Hebei (0.741). This was due to the gradual optimization of Beijing's economic development structure and the quality of economic development in the context of the Beijing-Tianjin-Hebei coordinated development strategy, and the economic development index increased by $5 \%$ year-on-year. At this time, Beijing's GDP growth reached $8.2 \%$; the total retail sales of consumer goods in Beijing reached 1174.77 billion yuan, 2.1 times and 0.7 times that of Tianjin (553.3 billion yuan) and Hebei (1653.71 billion yuan); Beijing's industrial added value reached 446.46 billion yuan, 0.6 times and 0.4 times that of Tianjin (696.271 billion yuan) and Hebei (1150.3 billion yuan); the output value of the tertiary industry accounted for $81 \%$ of GDP, which was higher than Tianjin (58.6\%) and Hebei $(46.2 \%)$; the overall labor productivity reached 244,067 yuan/person, which was 1.2 times and 2.9 times that of Tianjin $(210,001$ yuan/person) and Hebei $(85,602$ yuan/person) respectively. In summary, the economic development of Beijing and Hebei showed a sustained upward trend and the results of economic development were both relatively good. Tianjin's early economic development momentum was strong and its development process was good. 


\subsection{Dynamic Comparison of Social Governance Level}

Hebei region from 2010 to 2018, as shown in "Figure 2".

Taking 2009 as the base year, it determines the social governance level of the Beijing-Tianjin-

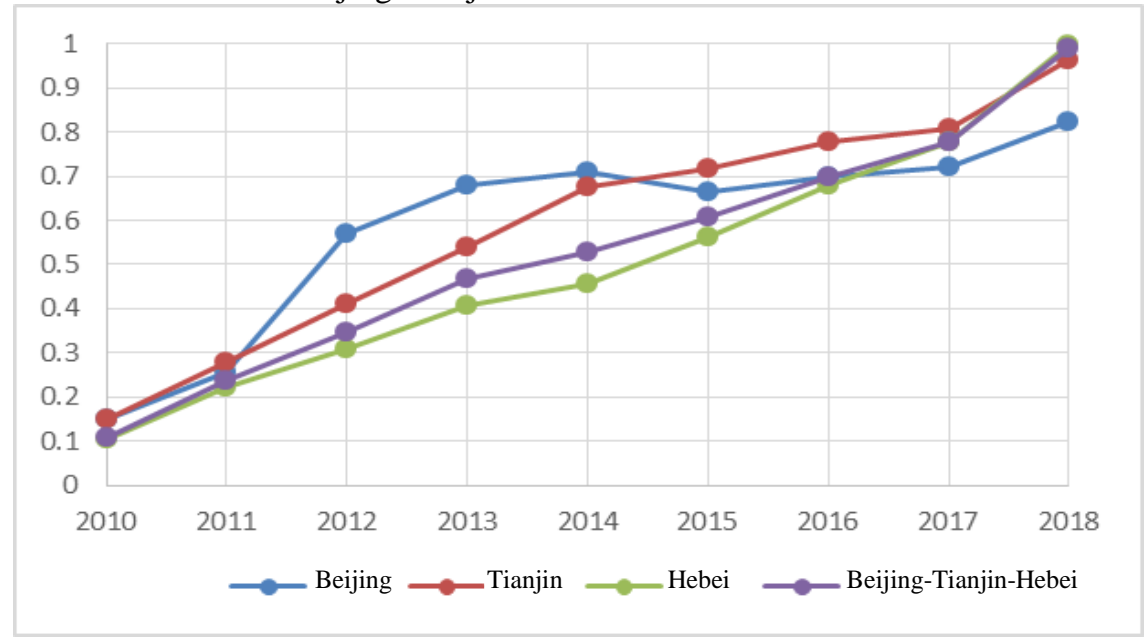

Figure 2 The level of social governance in the Beijing-Tianjin-Hebei region.

It can be seen from "Figure 2" that from 2010 to 2018, the overall social governance level of the Beijing-Tianjin-Hebei region showed an increasing trend; the changes in the social governance level of the Beijing-Tianjin-Hebei region showed a multitemporal nature. By 2018, the level of social governance in the Beijing-Tianjin-Hebei region showed the rule of Hebei (0.996)> Tianjin (0.964)> Beijing (0.825). At this time, the urban registered unemployment rate in Hebei dropped from $3.9 \%$ to $3.3 \%$, with an average annual drop of $0.8 \%$; the year-end balance of RMB savings deposits of urban and rural residents rose from 156.784 billion yuan to 4035.56 billion yuan, with an average annual increase of 308.465 billion yuan and an average annual growth rate of up to $20 \%$; the number of students enrolled in general institutes of higher education increased from 339,100 to 422,000 , with an average annual increase of 10,400 and an average annual growth rate of $3 \%$; the studentteacher ratio in general institutes of higher education dropped from 17.8 to 17.39 , with an average annual decline rate of $0.3 \%$; the local fiscal expenditure on education rose from 51.43 billion yuan to 138.559 billion yuan, with an average annual increase of 10.9 billion yuan and an average annual growth rate of $21 \%$; the year-end mobile phone users rose from 43.536 million to 81.956 million, with an average annual increase of 4.8 million and an average annual growth rate of $11 \%$; the length of railroad lines in service increased from 4,900 kilometers to 7,400 kilometers, with an average annual increase of 300 kilometers and an average annual growth rate of $6 \%$; the number of beds in medical and health institutions rose from 249,700 to 422,000 , with an average annual increase of 22,000 and an average annual growth rate of $9 \%$; the year-end number of insured people in the basic medical insurance for urban employees rose from 8.48 million to 10.302 million, with an average annual increase of 230,000 and an average annual growth rate of $3 \%$. To sum up, Beijing's early social governance level was relatively good, Tianjin and Hebei developed faster in the later stage, but Hebei's social governance achieved the best results.

\section{DYNAMIC EVALUATION OF THE LEVEL OF COORDINATED ECONOMIC DEVELOPMENT AND COORDINATED SOCIAL GOVERNANCE IN BEIJING- TIANJIN-HEBEI REGION}

According to formula (1) and formula (2), it determines the level of coordinated economic development, relative economic development, coordinated social governance and relative development of social governance in the BeijingTianjin-Hebei region, as shown in "Table 3" and "Table 4". 
Table 3. The level of coordinated economic development and relative economic development in Beijing-TianjinHebei region

\begin{tabular}{|c|c|c|c|c|c|c|c|c|c|c|c|c|c|c|}
\hline \multirow[t]{2}{*}{ Year } & \multicolumn{4}{|c|}{ Beijing-Tianjin } & \multicolumn{4}{|c|}{ Beijing-Hebei } & \multicolumn{4}{|c|}{ Tianjin-Hebei } & \multicolumn{2}{|c|}{$\begin{array}{l}\text { Beijing-Tianjin- } \\
\text { Hebei region }\end{array}$} \\
\hline & $\mathrm{D}$ & Rating & $\mathrm{E}$ & Stage & $D$ & Rating & $E$ & Stage & D & Rating & $\mathrm{E}$ & Stage & D & Rating \\
\hline 2010 & 0.58 & $\begin{array}{l}\text { Reluctant } \\
\text { coordination }\end{array}$ & 0.98 & $\begin{array}{l}\text { Synchro } \\
\text { nization }\end{array}$ & 0.57 & $\begin{array}{l}\text { Reluctant } \\
\text { coordination }\end{array}$ & 1.04 & $\begin{array}{l}\text { Synchroni } \\
\text { zation }\end{array}$ & 0.57 & $\begin{array}{l}\text { Reluctant } \\
\text { coordination }\end{array}$ & 1.07 & $\begin{array}{l}\text { Synchroni } \\
\text { zation }\end{array}$ & 0.57 & $\begin{array}{l}\text { Reluctant } \\
\text { coordination }\end{array}$ \\
\hline 2011 & 0.67 & $\begin{array}{l}\text { Primary } \\
\text { coordination }\end{array}$ & 0.84 & $\begin{array}{l}\text { Synchro } \\
\text { nization }\end{array}$ & 0.68 & \begin{tabular}{|l|} 
Primary \\
coordination
\end{tabular} & 0.83 & $\begin{array}{l}\text { Synchroni } \\
\text { zation }\end{array}$ & 0.71 & $\begin{array}{l}\text { Intermediate } \\
\text { coordination }\end{array}$ & 0.98 & $\begin{array}{l}\text { Synchroni } \\
\text { zation }\end{array}$ & 0.68 & $\begin{array}{l}\text { Primary } \\
\text { coordination }\end{array}$ \\
\hline 2012 & 0.67 & $\begin{array}{l}\text { Primary } \\
\text { coordination }\end{array}$ & 0.71 & Lag & 0.64 & \begin{tabular}{|l|} 
Primary \\
coordination
\end{tabular} & 0.83 & $\begin{array}{l}\text { Synchroni } \\
\text { zation }\end{array}$ & 0.70 & $\begin{array}{l}\text { Primary } \\
\text { coordination }\end{array}$ & 1.17 & $\begin{array}{l}\text { Synchroni } \\
\text { zation }\end{array}$ & 0.67 & $\begin{array}{l}\text { Primary } \\
\text { coordination }\end{array}$ \\
\hline 2013 & 0.74 & $\begin{array}{l}\text { Intermediate } \\
\text { coordination }\end{array}$ & O 77 & Lag & 0.71 & $\begin{array}{l}\text { Intermediate } \\
\text { coordination }\end{array}$ & 0.93 & $\begin{array}{l}\text { Synchroni } \\
\text { zation }\end{array}$ & 0.76 & $\begin{array}{l}\text { Intermediate } \\
\text { coordination }\end{array}$ & 1.21 & $\begin{array}{l}\text { Pulling } \\
\text { ahead }\end{array}$ & 0.74 & $\begin{array}{l}\text { Intermediate } \\
\text { coordination }\end{array}$ \\
\hline 2014 & 0.76 & $\begin{array}{l}\text { Intermediate } \\
\text { coordination }\end{array}$ & 0.73 & Lag & 0.72 & $\begin{array}{l}\text { Intermediate } \\
\text { coordination }\end{array}$ & 0.91 & $\begin{array}{l}\text { Synchroni } \\
\text { zation }\end{array}$ & 0.77 & $\begin{array}{l}\text { Intermediate } \\
\text { coordination }\end{array}$ & 1.25 & $\begin{array}{l}\text { Pulling } \\
\text { ahead }\end{array}$ & .75 & $\begin{array}{l}\text { Intermediate } \\
\text { coordination }\end{array}$ \\
\hline 2015 & 0.79 & $\begin{array}{l}\text { Intermediate } \\
\text { coordination }\end{array}$ & 0.81 & $\begin{array}{l}\text { Synchro } \\
\text { nization }\end{array}$ & 0.74 & $\begin{array}{l}\text { Intermediate } \\
\text { coordination }\end{array}$ & 1.05 & $\begin{array}{l}\text { Synchroni } \\
\text { zation }\end{array}$ & 0.78 & $\begin{array}{l}\text { Intermediate } \\
\text { coordination }\end{array}$ & 1.29 & $\begin{array}{l}\text { Synchroni } \\
\text { zation }\end{array}$ & 0.77 & $\begin{array}{l}\text { Intermediate } \\
\text { coordination }\end{array}$ \\
\hline 2016 & 0.88 & $\begin{array}{l}\text { Good } \\
\text { coordination }\end{array}$ & 0.94 & $\begin{array}{l}\text { Synchro } \\
\text { nization }\end{array}$ & 0.85 & $\begin{array}{l}\text { Good } \\
\text { coordination }\end{array}$ & 1.05 & $\begin{array}{l}\text { Synchroni } \\
\text { zation }\end{array}$ & 0.87 & $\begin{array}{l}\text { Good } \\
\text { coordination }\end{array}$ & 1.12 & $\begin{array}{l}\text { Synchroni } \\
\text { zation }\end{array}$ & 0.87 & $\begin{array}{l}\text { Good } \\
\text { coordination }\end{array}$ \\
\hline 2017 & 0.88 & $\begin{array}{l}\text { Good } \\
\text { coordination }\end{array}$ & 0.97 & $\begin{array}{l}\text { Synchro } \\
\text { nization }\end{array}$ & 0.88 & $\begin{array}{l}\text { Good } \\
\text { coordination }\end{array}$ & 0.97 & $\begin{array}{l}\text { Synchroni } \\
\text { zation }\end{array}$ & 0.89 & $\begin{array}{l}\text { Good } \\
\text { coordination }\end{array}$ & 1.00 & $\begin{array}{l}\text { Synchroni } \\
\text { zation }\end{array}$ & 0.88 & $\begin{array}{l}\text { Good } \\
\text { coordination }\end{array}$ \\
\hline 18 & 0.89 & $\begin{array}{l}\text { Good } \\
\text { coordination }\end{array}$ & 1.05 & $\begin{array}{l}\text { Synchro } \\
\text { nization }\end{array}$ & .88 & $\begin{array}{l}\text { High-quality } \\
\text { coordination }\end{array}$ & 1.09 & $\begin{array}{l}\text { Synchroni } \\
\text { zation }\end{array}$ & 0.87 & $\begin{array}{l}\text { Good } \\
\text { coordination }\end{array}$ & 1.04 & $\begin{array}{l}\text { Synchroni } \\
\text { zation }\end{array}$ & 0.88 & $\begin{array}{l}\text { Good } \\
\text { coordination }\end{array}$ \\
\hline
\end{tabular}

Researches show that on one hand, from the perspective of coordinated economic development level, the coordinated economic development level of the Beijing-Tianjin-Hebei region showed an increasing trend, the coordinated development level rose from 0.57 to 0.88 , and the coordinated rating transitioned from "reluctant coordination" to "good coordination". From 2010 to 2018, the level of coordinated economic development of BeijingTianjin increased from 0.58 to 0.89 , the level of coordinated economic development of BeijingHebei increased from 0.57 to 0.88 , the level of coordinated economic development of TianjinHebei increased from 0.57 to 0.87 , and the level of coordinated economic development of BeijingTianjin was generally better than Beijing-Hebei and Tianjin-Hebei. On the other hand, from the perspective of the relative economic development level, the relative economic development levels of Beijing-Tianjin, Beijing-Hebei and Tianjin-Hebei were basically in the "synchronization" stage. On the whole, the level of economic development among Beijing, Tianjin and Hebei was relatively close, the relative development was relatively balanced, and the regional economic integration achieved remarkable results, which promoted the coordinated economic development of the BeijingTianjin-Hebei region.

Table 4. The level of coordinated social governance and the relative development level of social governance in Beijing-Tianjin-Hebei region

\begin{tabular}{|c|c|c|c|c|c|c|c|c|c|c|c|c|c|}
\hline \multirow{2}{*}{ Year } & \multicolumn{3}{|c|}{ Beijing-Tianjin } & \multicolumn{4}{|c|}{ Beijing-Hebei } & \multicolumn{4}{|c|}{ Tianjin-Hebei } & \multicolumn{2}{|c|}{$\begin{array}{l}\text { Beijing-Tianjin-Hebei } \\
\text { region }\end{array}$} \\
\hline & D & Rating & Stage & D & Rating & $E$ & Stage & D & Rating & $E$ & Stage & $D$ & Rating \\
\hline 2010 & 0.39 & 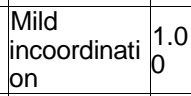 & $\begin{array}{l}\text { Synchroniz } \\
\text { ation }\end{array}$ & 0.35 & $\begin{array}{l}\text { Mild } \\
\text { incoordination }\end{array}$ & 1.44 & $\begin{array}{l}\text { Pulling } \\
\text { ahead }\end{array}$ & 0.35 & $\begin{array}{l}\text { Mild } \\
\text { incoordination }\end{array}$ & 1.44 & $\begin{array}{l}\text { Pulling } \\
\text { ahead }\end{array}$ & 0.36 & $\begin{array}{l}\text { Mild } \\
\text { incoordination }\end{array}$ \\
\hline 2011 & 0.52 & \begin{tabular}{l|l} 
Reluctant & 0.9 \\
coordination 3
\end{tabular} & $\begin{array}{l}\text { Synchroniz } \\
\text { ation }\end{array}$ & 0.49 & $\begin{array}{l}\text { On the verge of } \\
\text { incoordination }\end{array}$ & 1.15 & $\begin{array}{l}\text { Synchroni } \\
\text { zation }\end{array}$ & 0.50 & $\begin{array}{l}\text { On the verge } \\
\text { of } \\
\text { incoordination }\end{array}$ & 1.25 & $\begin{array}{l}\text { Pulling } \\
\text { ahead }\end{array}$ & 0.50 & $\begin{array}{l}\text { On the verge } \\
\text { of } \\
\text { incoordination }\end{array}$ \\
\hline 2012 & 0.70 & \begin{tabular}{|l|l|} 
Primary & 1.3 \\
coordination 8
\end{tabular} & $\begin{array}{l}\text { Pulling } \\
\text { ahead }\end{array}$ & 0.65 & $\begin{array}{l}\text { Primary } \\
\text { coordination }\end{array}$ & 1.84 & $\begin{array}{l}\text { Pulling } \\
\text { ahead }\end{array}$ & 0.60 & $\begin{array}{l}\text { Reluctant } \\
\text { coordination }\end{array}$ & 1.33 & $\begin{array}{l}\text { Pulling } \\
\text { ahead }\end{array}$ & 0.65 & \begin{tabular}{|l} 
Reluctant \\
coordination
\end{tabular} \\
\hline 2013 & 0.78 & \begin{tabular}{l|l} 
Intermediat & 1.2 \\
e & 6 \\
coordination & 6
\end{tabular} & $\begin{array}{l}\text { Pulling } \\
\text { ahead }\end{array}$ & 0.73 & $\begin{array}{l}\text { Intermediate } \\
\text { coordination }\end{array}$ & 1.68 & $\begin{array}{l}\text { Pulling } \\
\text { ahead }\end{array}$ & 0.68 & $\begin{array}{l}\text { Primary } \\
\text { coordination }\end{array}$ & 1.33 & $\begin{array}{l}\text { Pulling } \\
\text { ahead }\end{array}$ & 0.73 & $\begin{array}{l}\text { Intermediate } \\
\text { coordination }\end{array}$ \\
\hline 2014 & 0.83 & \begin{tabular}{l|l} 
Good & 1.0 \\
coordination 5
\end{tabular} & $\begin{array}{l}\text { Synchroniz } \\
\text { ation }\end{array}$ & 0.75 & $\begin{array}{l}\text { Intermediate } \\
\text { coordination }\end{array}$ & 1.56 & $\begin{array}{l}\text { Pulling } \\
\text { ahead }\end{array}$ & 0.74 & $\begin{array}{l}\text { Intermediate } \\
\text { coordination }\end{array}$ & 1.48 & $\begin{array}{l}\text { Pulling } \\
\text { ahead }\end{array}$ & 0.78 & $\begin{array}{l}\text { Intermediate } \\
\text { coordination }\end{array}$ \\
\hline 2015 & 0.83 & \begin{tabular}{l|l} 
Good & 0.9 \\
coordination & 2 \\
\end{tabular} & $\begin{array}{l}\text { Synchroniz } \\
\text { ation }\end{array}$ & 0.78 & $\begin{array}{l}\text { Intermediate } \\
\text { coordination }\end{array}$ & 1.18 & $\begin{array}{l}\text { Synchroni } \\
\text { zation }\end{array}$ & 0.80 & $\begin{array}{l}\text { Intermediate } \\
\text { coordination }\end{array}$ & 1.28 & $\begin{array}{l}\text { Pulling } \\
\text { ahead }\end{array}$ & 0.80 & $\begin{array}{l}\text { Intermediate } \\
\text { coordination }\end{array}$ \\
\hline 2016 & 0.86 & \begin{tabular}{l|l} 
Good & 0.8 \\
coordination 9
\end{tabular} & $\begin{array}{l}\text { Synchroniz } \\
\text { ation }\end{array}$ & 0.83 & $\begin{array}{l}\text { Good } \\
\text { coordination }\end{array}$ & 1.03 & $\begin{array}{l}\text { Synchroni } \\
\text { zation }\end{array}$ & 0.85 & $\begin{array}{l}\text { Good } \\
\text { coordination }\end{array}$ & 5 & $\begin{array}{l}\text { Synchro } \\
\text { nization }\end{array}$ & 0.85 & $\begin{array}{l}\text { Good } \\
\text { coordination }\end{array}$ \\
\hline 2017 & 0.87 & \begin{tabular}{l|l} 
Good & 0.8 \\
coordination 9
\end{tabular} & $\begin{array}{l}\text { Synchroniz } \\
\text { ation }\end{array}$ & 0.87 & $\begin{array}{l}\text { Good } \\
\text { coordination }\end{array}$ & 0.92 & $\begin{array}{l}\text { Synchroni } \\
\text { zation }\end{array}$ & 0.89 & $\begin{array}{l}\text { Good } \\
\text { coordination }\end{array}$ & 1.04 & $\begin{array}{l}\text { Synchro } \\
\text { nization }\end{array}$ & 0.88 & $\begin{array}{l}\text { Good } \\
\text { coordination }\end{array}$ \\
\hline 2018 & 0.94 & $\begin{array}{l}\text { High-quality } 0.8 \\
\text { coordination } 6\end{array}$ & $\begin{array}{l}\text { Synchroniz } \\
\text { ation }\end{array}$ & 0.95 & $\begin{array}{l}\text { High-quality } \\
\text { coordination }\end{array}$ & 0.83 & $\begin{array}{l}\text { Synchroni } \\
\text { zation }\end{array}$ & 0.99 & $\begin{array}{l}\text { High-quality } \\
\text { coordination }\end{array}$ & 0.97 & $\begin{array}{l}\text { Synchro } \\
\text { nization }\end{array}$ & C & $\begin{array}{l}\text { High-quality } \\
\text { coordination }\end{array}$ \\
\hline
\end{tabular}


Studies show that on one hand, from the perspective of the level of coordinated social governance, the level of coordinated social governance in Beijing-Tianjin-Hebei region showed an increasing trend, with the coordinated degree rising from 0.36 to 0.96 , and the coordinated rating transitioned from "mild incoordination" to "high-quality coordination". From 2010 to 2016, the Beijing-Tianjin coordinated social governance level rose from 0.39 to 0.86 , the Beijing-Hebei coordinated social governance level rose from 0.35 to 0.83 , and the Tianjin-Hebei coordinated social governance level rose from 0.35 to 0.85 . The level of Beijing-Tianjin social coordination governance was generally better than Beijing-Hebei and Tianjin-Hebei. On the other hand, from the perspective of the relative development level of social governance, the relative development level of social governance in Beijing-Tianjin, Beijing-Hebei and Tianjin-Hebei was in the stage of "synchronization-pulling ahead-synchronization". On the whole, Beijing-Tianjin social governance had a high degree of coordination and relatively balanced development, while the overall development of Hebei's social governance level and speed was slow, resulting in the lack of obvious advantages of coordinated social governance of Beijing-Hebei and Tianjin-Hebei, thus delaying the coordinated social governance of Beijing-TianjinHebei region.

\section{EVALUATION OF THE COORDINATION LEVEL BETWEEN ECONOMIC DEVELOPMENT AND SOCIAL GOVERNANCE IN BEIJING- TIANJIN-HEBEI REGION}

It adopts the relative development degree model and the coupling coordination model to measure the coordination level of Beijing-Tianjin-Hebei region's economic development and social governance (see "Table 5").

It can be seen from "Table 5" that: On one hand, from 2010 to 2018, the coordination level of the Beijing-Tianjin-Hebei region's economic development and social governance showed an increasing trend, the coordination degree rose from 0.43 to 0.93 , and the coordination rating transitioned from "on the verge of imbalance" to "high-quality coordination". From the perspective of the change trend of the coordination level, the coordinated development of economic development and social governance in Tianjin from 2010 to 2014 was relatively fast, and the coordination degree increased from 0.47 to 0.82 , with an average annual growth of 0.15 ; Beijing and Tianjin slowed down the coordinated development of economic development and social governance from 2015 to 2018, and the coordination degree increased from 0.77 and 0.82 to 0.903 and 0.93 , with an average annual growth of 0.04 and 0.03 respectively. The coordinated development speed of Hebei's economic development and social governance from 2010 to 2018 was relatively fast, and the coordination degree increased from 0.42 to 0.93 , with an average annual growth of 0.1 . From the perspective of coordination rating, Beijing, Tianjin, and Hebei simultaneously entered the "high-quality coordination" development stage of economic development and social governance.

On the other hand, the relative development of the Beijing-Tianjin-Hebei region's economic development and social governance went through the stage of "pulling ahead-synchronization-lag". From 2010 to 2017, the economic development changed from influencing social governance to promoting social governance, and the system tended to be optimized. Among them, the relative development relationship between Beijing's economic development and social governance was unstable, showing the characteristics of "pulling ahead-lag-synchronization" and "influencingrestricting-promoting". From 2010 to 2012, Tianjin was in the stage of leading economic development and influencing social governance, and from 2013 to 2018, it was in the stage of synchronizing economic development and promoting social governance. Hebei was in the stage of leading economic development and influencing social governance from 2010 to 2013. From 2014 to 2017, it was in the stage of synchronizing economic development and promoting social governance. However, in 2018, it was in the stage of lagging economic development and restricting social governance. 
Table 5. Evaluation of coordination level between economic development and social governance in BeijingTianjin-Hebei region

\begin{tabular}{|c|c|c|c|c|c|}
\hline Region & Year & D & Rating & $E$ & Stage \\
\hline \multirow{9}{*}{ Beijing } & 2010 & 0.47 & On the verge of imbalance & 2.21 & Pulling ahead \\
\hline & 2011 & 0.57 & Reluctant coordination & 1.62 & Pulling ahead \\
\hline & 2012 & 0.68 & Primary coordination & 0.67 & Lag \\
\hline & 2013 & 0.76 & Intermediate coordination & 0.71 & Lag \\
\hline & 2014 & 0.77 & Intermediate coordination & 0.69 & Lag \\
\hline & 2015 & 0.78 & Intermediate coordination & 0.85 & Synchronization \\
\hline & 2016 & 0.85 & Good coordination & 1.07 & Synchronization \\
\hline & 2017 & 0.86 & Good coordination & 1.07 & Synchronization \\
\hline & 2018 & 0.903 & High-quality coordination & 0.97 & Synchronization \\
\hline \multirow{9}{*}{ Tianjin } & 2010 & 0.47 & On the verge of imbalance & 2.27 & Pulling ahead \\
\hline & 2011 & 0.61 & Primary coordination & 1.78 & Pulling ahead \\
\hline & 2012 & 0.68 & Primary coordination & 1.29 & Pulling ahead \\
\hline & 2013 & 0.76 & Intermediate coordination & 1.16 & Synchronization \\
\hline & 2014 & 0.82 & Good coordination & 1.00 & Synchronization \\
\hline & 2015 & 0.84 & Good coordination & 0.97 & Synchronization \\
\hline & 2016 & 0.89 & Good coordination & 1.02 & Synchronization \\
\hline & 2017 & 0.89 & Good coordination & 0.98 & Synchronization \\
\hline & 2018 & 0.93 & High-quality coordination & 0.80 & Synchronization \\
\hline \multirow{9}{*}{ Hebei } & 2010 & 0.42 & On the verge of imbalance & 3.06 & Pulling ahead \\
\hline & 2011 & 0.58 & Reluctant coordination & 2.26 & Pulling ahead \\
\hline & 2012 & 0.61 & Primary coordination & 1.47 & Pulling ahead \\
\hline & 2013 & 0.68 & Primary coordination & 1.29 & Pulling ahead \\
\hline & 2014 & 0.70 & Primary coordination & 1.18 & Synchronization \\
\hline & 2015 & 0.74 & Intermediate coordination & 0.96 & Synchronization \\
\hline & 2016 & 0.83 & Intermediate coordination & 1.05 & Synchronization \\
\hline & 2017 & 0.89 & Good coordination & 1.02 & Synchronization \\
\hline & 2018 & 0.93 & High-quality coordination & 0.74 & Lag \\
\hline \multirow{9}{*}{$\begin{array}{l}\text { Beijing- } \\
\text { Tianjin-Hebei } \\
\text { region }\end{array}$} & 2010 & 0.43 & On the verge of imbalance & 3.05 & Pulling ahead \\
\hline & 2011 & 0.58 & Reluctant coordination & 2.05 & Pulling ahead \\
\hline & 2012 & 0.63 & Primary coordination & 1.30 & Pulling ahead \\
\hline & 2013 & 0.71 & Intermediate coordination & 1.15 & Synchronization \\
\hline & 2014 & 0.74 & Intermediate coordination & 1.06 & Synchronization \\
\hline & 2015 & 0.77 & Intermediate coordination & 0.96 & Synchronization \\
\hline & 2016 & 0.85 & Good coordination & 1.06 & Synchronization \\
\hline & 2017 & 0.88 & Good coordination & 1.01 & Synchronization \\
\hline & 2018 & 0.93 & High-quality coordination & 0.77 & Lag \\
\hline
\end{tabular}

In summary, from 2010 to 2018 , the level of coordinated development of the Beijing-TianjinHebei region's economic development and social governance showed an overall increasing trend, and the coordination rating transitioned from "on the verge of imbalance" to "high-quality coordination"; from 2010 to 2017, the relative development of the economic development and social governance of the Beijing-Tianjin-Hebei region went through the stage of "pulling ahead-synchronization", the economic development changed from influencing social governance to promoting social governance, and the system tended to be optimized. From the perspective of coordination rating, Beijing, Tianjin, 
and Hebei simultaneously entered the "high-quality coordination" development stage of economic development and social governance.

\section{CONCLUSION}

From 2010 to 2018, the level of economic development and social governance in BeijingTianjin-Hebei was remarkable. First of all, the level of economic development in the Beijing-TianjinHebei region was remarkable. Among them, Beijing and Hebei showed a trend of continued improvement and their development results were both good; Tianjin's economic development momentum was strong, its economic development speed was relatively fast, and the economic development level in the later period slightly declined. In addition, the level of social governance in the Beijing-Tianjin-Hebei region was remarkable. Among them, Beijing, Tianjin and Hebei generally showed a trend of seeking progress while maintaining stability. Beijing's early social governance level was relatively good, Tianjin and Hebei developed faster in the later stage, but Hebei's social governance achieved the best results. The coordination degree between the economic development and social governance of BeijingTianjin-Hebei region showed an increasing trend, and the economic development changed from influencing social governance to promoting social governance; Beijing, Tianjin, and Hebei simultaneously entered the stage of "high-quality coordination" of economic development and social governance.

Regarding the economic scale, Beijing, Tianjin and Hebei had the problem of overall decline in GDP growth; at the same time, in view of the economic structure, Beijing, Tianjin and Hebei had the problem that the output value of the tertiary industry as a proportion of GDP increased slowly. For this reason, the Beijing-Tianjin-Hebei region urgently needs to accelerate the transformation and upgrading of economic structure and promote the improvement of the quality of economic development. The specific countermeasures include: First, in terms of system, it is necessary to accelerate the reform of the economic and technological systems and promote the development of high-tech and high-value-added industries. Second, at the government and enterprise level, it is needed to build a TianjinHebei non-capital function acceptance platform to relieve non-capital functional industries and support the development of high-end industries that meet the functional positioning of the capital; efforts should also be made to accelerate industrial integration, take supply-side structural reforms as the orientation, and promote the in-depth integration of manufacturing and service industries.

Regarding the improvement of people's livelihood, Beijing and Hebei have the problem of a slight increase in urban registered unemployment rates in the later period; regarding the educational governance, Beijing has the problem of a slight decline in the number of students enrolled in general institutes of higher education in the later period as well as the unstable student-teacher ratio in general institutes of higher education; the student-teacher ratio in general institutes of higher education in Tianjin has continued to decline, and local financial expenditures on education have decreased in the later period; the number of students enrolled in general institutes of higher education has dropped sharply in the medium term, and the student-teacher ratio in general institutes of higher education is relatively low. For this reason, the Beijing-Tianjin-Hebei region urgently needs to continue to improve people's livelihood and strengthen education governance. The specific countermeasures include: First, it is necessary to implement the employment priority strategy in depth, and increase the implementation of assistance to enterprises to stabilize jobs; efforts need to be made to promote employment and entrepreneurship of key groups, effectively strengthen vocational training and employment services, and maintain a stable employment situation; it is also needed to promote the transfer employment of rural labor and the return of rural migrant workers to hometown to start a businesses. Second, it is necessary to introduce outstanding talents in China and foreign countries, and increase the number of authorized teachers to supplement the number of teachers in colleges and universities; it is needed to comprehensively consider factors such as the shortage of majors in economic and social governance, and strive to expand the scale of enrollment. Third, efforts should be made to standardize the division of central and local educational finance powers or authority of office and expenditure responsibilities to relieve the pressure on local fiscal education expenditures.

\section{AUTHORS' CONTRIBUTIONS}

Dan $\mathrm{Wu}$ is responsible for experimental design and writing, and Xiaoqian Xiang analysed data and wrote the manuscript. 


\section{REFERENCES}

[1] Zhang Zhanbin. The Great Strategic Significance of the Coordinated Development of Beijing-Tianjin-Hebei Region [J]. Environmental Protection, 2014,17:18-20. (in Chinese)

[2] Bo Wenguang, Chen Fei. The Coordinated Development of Beijing-Tianjin-Hebei Region: Challenges and Dilemmas [J]. Nankai Journal (Philosophy and Social Sciences Edition), 2015(1):110-118. (in Chinese)

[3] Sun Jiuwen. The Goal, Task and Implementation Path of the Coordinated Development of Beijing-Tianjin-Hebei Region [J]. Comparative Economic \& Social Systems, 2016(3):5-9. (in Chinese)

[4] Sun Jiuwen, Yao Peng. Spatial Transfer, Regional Specialization and Coordinated Development of Industries in the BeijingTianjin-Hebei Region — an Analysis Framework Based on New Economic Geography [J]. Nankai Journal (Philosophy and Social Sciences Edition), 2015(1):81-89. (in Chinese)

[5] Wei Lihua. The Historical Context and Stage Characteristics of the Coordinated Development of Beijing-Tianjin-Hebei Region Since the Founding of the People's Republic of China [J]. Journal of Shenzhen University (Humanities and Social Sciences Edition), 2016,06:143-150. (in Chinese)

[6] Chen Hong, Yang Liu. Research on the Issues of Beijing-Tianjin-Hebei Regional Economic Integration [J]. Modern Management Science, 2016(09):78-80. (in Chinese)

[7] Liu Hao, Ma Lin, Li Guoping. The Spatiotemporal Evolution of the Unbalanced Pattern of Economic Development in the Beijing-Tianjin-Hebei Region Since the 1990s [J]. Geographical Research, 2016,35(03):471481. (in Chinese)

[8] Cheng Hui, Zhao Jianhua. The Status Quo, Obstacles and Breakthroughs of the Regional Economic Integration of Beijing-TianjinHebei Region [J]. People's Tribune, 2014(29):95-97. (in Chinese)

[9] Cui Dongchu, Song Zhijie. Problems and Countermeasures in the Regional Economic
Integration of Beijing-Tianjin-Hebei Region [J]. Economic Review, 2012(05):75-78. (in Chinese)

[10] Guo Ping, Liu Guifen. The Measurement of the Differences in the Development of Social Undertakings in China from the Perspective of Synergy - Taking the Representative Provinces in the Three Major Regions as Examples $[\mathrm{J}]$. Huxiang Forum, 2014,27(01):58-63. (in Chinese)

[11] Xie Yanzhi. Creating a New Era of Coordinated Development of Social Work in Beijing-Tianjin-Hebei Region [J]. China Social Work, 2017(34):18-19. (in Chinese)

[12] Zhou Bo, Zhang Wenling, Zhang Guodong, et al. Research on the Regional Integration of Social Insurance in Beijing-Tianjin-Hebei Region [J]. Knowledge Economy, 2017(24):23. (in Chinese)

[13] Research Group of the Macroeconomic Research Institute of Hebei Development and Reform Commission. Research on Promoting the Equalization of Basic Public Services in Beijing-Tianjin-Hebei Region [J]. Review of Economic Research, 2018(15):55-64. (in Chinese)

[14] Wang Chunrui. Research on the Impact and Countermeasures of Migration Movement Under the Beijing-Tianjin-Hebei Coordinated Development Strategy $[\mathrm{J}]$. Review of Economic Research, 2016(64):46-49. (in Chinese)

[15] Li Xu. The Current Situation, Difficulties and Countermeasures of the Construction of the Beijing-Tianjin-Hebei Regional University Alliance [J]. Higher Education Research, 2018,39(06):42-50. (in Chinese)

[16] Jia Shanshan, Yang Fei, Feng Zhenhuan. Evaluation of the Vulnerability of Regional Social System — Taking the Beijing-TianjinHebei Metropolitan Area as an Example [J]. Commercial Times, 2014(32):131-132. (in Chinese)

[17] Zheng Chen, Dong Wu. Research on BeijingTianjin-Hebei Emergency Response Mechanism from the Perspective of Vulnerability $[\mathrm{J}]$. Journal of Tianjin Administration Institute, 2018,20(04):36-42. (in Chinese) 
[18] Tian Xuebin, Chen Yidan. Differential Characteristics and Trends of Equalization of Basic Public Services in Beijing-TianjinHebei Region [J]. Economy and Management, 2019,33(06):7-15. (in Chinese)

[19] Li Dong. Evaluation of Public Service Quality in Beijing-Tianjin-Hebei Region [J]. Areal Research and Development, 2018,37(02):5257. (in Chinese)

[20] Wu Yiqing, Zhao Jianqiang. Measurement of Regional Integration Level of Basic Public Services — Taking the Beijing-Tianjin-Hebei Region and Yangtze River Delta as Examples [J]. Economy and Management, 2017, 31(04): 11-16. (in Chinese)

[21] Jiang Xi, Liu Yingying. Research on the Equalization of Public Services in BeijingTianjin-Hebei Region [J]. Journal of Commercial Economics, 2017(03):211-213. (in Chinese) 